\title{
Placental and stillbirth tissue lead concentrations in occupationally exposed women
}

\author{
A K KHERA, ${ }^{1}$ D G WIBBERLEY, ${ }^{1}$ AND J G DATHAN ${ }^{2}$ \\ From the Department of Pharmacy, ${ }^{1}$ University of Aston, Gosta Green, Birmingham B4 7ET, and \\ Wolstanton, ${ }^{2}$ Newcastle-under-Lyme, Staffs ST5 OHB, UK
}

ABSTRACT The lead values in maternal and infant blood, in placental tissue, and in stillbirth liver, kidney, and rib- and skull-bones have been determined in samples from the Stoke-on-Trent area. The lead values in antenatal blood and placenta increase with occupational exposure; liver and kidney stillbirth lead values are lower than those of much older children and rib-bone lead values from stillbirths were on average three times as high as those from a control group comprised of cot deaths and early infant deaths from accidental causes.

The abortifactant properties of lead salts in moderate to high doses and the high rate of miscarriage in women working in a poorly controlled environment containing lead are well documented (see references within Waldron and Stöfen ${ }^{1}$ ), as are the teratogenic effects of lead alone, and with cadmium, in animals. ${ }^{2-4}$ What is not certain, however, is whether low concentrations of lead have any effect on the human fetus. Some workers, on the basis of a few cases, have claimed that lead can be teratogenic ${ }^{56}$ while others ${ }^{7}$ suggest that the case is not proved. Our own work on Birmingham mothers showed that placental-lead concentrations were appreciably higher in cases of stillbirth or neonatal death, but our results did not distinguish between causative and consequential effects. ${ }^{8}$ In the present investigation we have examined lead values in various tissues from women employed in the pottery industry in Stokeon-Trent.

\section{Tissue samples}

Placentae, blood, stillbirth bone, liver, and kidney were supplied by JGD (formerly of the Health and Safety Executive) from mothers employed in the pottery industry in Stoke-on-Trent. Records were available for the occupation of the women from whom blood and placental samples had been taken. Placentae and stillbirth samples were stored at

Received 7 January 1980

Accepted 20 February 1980 $-20^{\circ} \mathrm{C}$, and the time of storage before analysis varied from 6 to 12 months. Blood samples were analysed within a few days of collection. Control samples of infant bones were supplied by Dr H A Waldron (London School of Hygiene and Tropical Medicine) and consisted of cot-deaths (age under 1 week) and accidental deaths (age under 18 weeks).

Stillbirth bone samples were wet-digested with nitric acid and diluted solutions analysed by graphite furnace atomic absorption spectrophotometry(AAS). Placental, liver, and kidney samples were solubilised with Soluene $-\mathbf{3 5 0}$ and diluted solutions analysed by graphite furnace AAS using our previously reported method. ${ }^{910}$ Blood samples were analysed at the medical laboratory of the Health and Safety Executive.

\section{Placenta}

In several respects the placental-lead values gave similar results to our Birmingham investigation though with lower absolute values. Thus the placental-lead values where a stillbirth had occurred ( 20 cases) had a high average value $(0.45 \pm 0.32 \mu \mathrm{g} / \mathrm{g})$ compared with that from eight mothers who had not worked in industry during the previous two years $(0.29 \pm 0.09 \mu \mathrm{g} / \mathrm{g})$. The mean value for the nine mothers who had had a malformed live-birth was not high $(0.32 \pm 0.14 \mu \mathrm{g} / \mathrm{g})$ but in ten cases where record sheets gave some statement concerning fetal distress, the placental-lead values $(0.43 \pm 0.19 \mu \mathrm{g} / \mathrm{g})$ were close to those where a stillbirth had resulted. The average placental-lead value for all these Stokeon-Trent samples $(0 \cdot 35 \pm 0.23 \mu \mathrm{g} / \mathrm{g})$ was about one394 


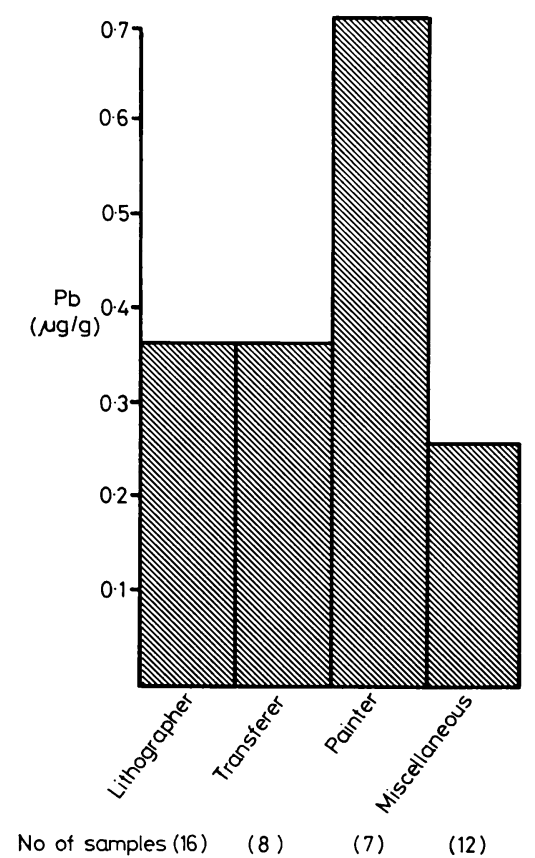

Fig 1 Relation between placental lead and type of occupation (normal births).

third that of our earlier reported values for 1971 Birmingham samples but appreciably higher than the value we now find for fresh Birmingham placentas (ca $0.12 \mu \mathrm{g} / \mathrm{g}$ ). We ascribe this difference to the precipitation of placental-lead with continued storage at $-20^{\circ} \mathrm{C}$ coupled with our method of sample

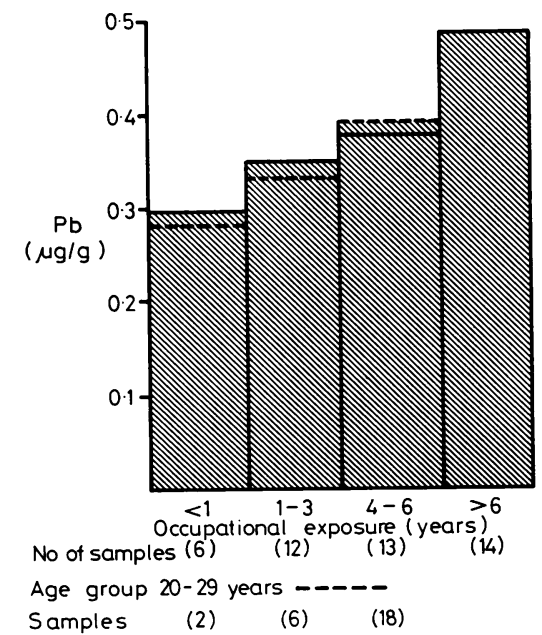

Fig 2 Relation between placental lead and duration of occupational exposure (normal births). preparation which entails the prior removal of excess fluid.

When comparing the results from the different occupational groups (fig 1) it was found that lithographers $(0.34 \pm 0.14 \mu \mathrm{g} / \mathrm{g})$ and transferers $(0.34 \pm$ $0 \cdot 16 \mu \mathrm{g} / \mathrm{g}$ ) had the same mean placental-lead value and that this was higher than that of the women described as following miscellaneous occupations $(0.25 \pm 0.07 \mu \mathrm{g} / \mathrm{g})$. One paintress had an exceptionally high value $(1.7 \mu \mathrm{g} / \mathrm{g})$, and even omitting this result, the average value for this group $(0.54 \pm$ $0.09 \mu \mathrm{g} / \mathrm{g}$ ) was significantly greater than for lithographers or transferers $(p<0.01)$. The placental-lead burden also increased appreciably with length of occupational exposure (fig 2). Although placental lead also increases with maternal age from an average value of $0.30 \pm 0.16 \mu \mathrm{g} / \mathrm{g}$ for age $<20,0.35 \pm 0.14$ $\mu \mathrm{g} / \mathrm{g}$ for age $20-29$ to $0.51 \pm 0.44 \mu \mathrm{g} / \mathrm{g}$ for age $\geqslant 30$, within a group of mothers aged 20-29 (26 samples) the placental-lead figures showed an increase with increasing job exposure (fig 2).

\section{Blood}

In common with sevaral other reports we find a highly significant positive correlation $(r=+0.40$, $\mathrm{p}=<0.001$ ) between lead values in maternal and infant blood (65 samples) but an insignificant correlation between maternal blood lead and placental lead $(\mathrm{r}=+0 \cdot 16)$. There was little variation between the lead values in maternal blood samples taken immediately before birth $(12 \pm 5 \mu \mathrm{g} / 100 \mathrm{ml})$ irrespective of occupation or length of employment, but when antenatal samples (mean value $17 \pm 7 \mu \mathrm{g}$ / $100 \mathrm{ml}$ ) are grouped, an occupational variation is apparent (table).

Antenatal blood-lead concentrations in different occupational groups

\begin{tabular}{llll}
\hline & Transferer & Lithographer & Paintress \\
\hline $\mathrm{Pb}(\mu \mathrm{g} / 100 \mathrm{ml})$ & 12 & $19 \pm 9$ & $24 \pm 9$ \\
No of samples & 2 & 27 & 11 \\
\hline
\end{tabular}

\section{Kidney and liver}

Lead values in 11 stillbirth kidney samples varied from 0.30 to $0.69 \mu \mathrm{g} / \mathrm{g}$ with a mean value of $0.48 \pm 0.13$ $\mu \mathrm{g} / \mathrm{g}$ (wet wt). The same stillbirths had liver-lead values of $0.02-1.12$ with a mean of $0.42 \pm 0.30 \mu \mathrm{g} / \mathrm{g}$. Previous workers have quoted liver and kidney values for stillbirths of 53 and $38 \mu \mathrm{g} / \mathrm{g}$ ash wt and for children aged 0-19 years of 74 and $62 \mu \mathrm{g} / \mathrm{g}$ ash wt respectively. ${ }^{11}$ No samples were available for comparison using our present analytical techniques. 


\section{Bones}

Lead values in 10-rib samples from stillbirths ranged from 0.73 to $3.75 \mu \mathrm{g} / \mathrm{g}$ with a mean value of $2.01 \pm$ $0.97 \mu \mathrm{g} / \mathrm{g}$ (wet wt basis). The lead values in skullbone samples from seven of the same births ranged from 0.36 to 2.53 with a mean of $1.28 \pm 0.66 \mu \mathrm{g} / \mathrm{g}$. The ratios of wet:dry weight $(1.85)$ and wet weight: ash (3.23) were in the expected range. A series of cot-deaths (age less than 1 week) and two infant deaths (age less than 18 weeks) yielded rib-bone lead values of $0.72 \pm 0.46 \mu \mathrm{g} / \mathrm{g}$, which was significantly lower than the stillbirth ribs $(p<0.001)$.

\section{Conclusion}

Women working in the Stoke-on-Trent area in jobs exposed to lead have higher antenatal blood lead concentrations and higher than average placentallead concentrations. In addition, concentrations of lead in stillbirth tissues appear to be high and, in the case of rib-bone lead where we were able to make direct comparisons, there is an accumulation of lead. It is not possible to say, however, whether the occupational lead exposure caused any of the stillbirths that were examined or whether the high lead values were consequential to the fetal death. Nevertheless, even in the absence of any direct causal evidence of the subclinical effects of lead, we would regard it as only prudent to ensure that wherever possible lead is removed from the environment of the pregnant worker. The ethical implications with respect to the continuation of employment of women in such an environment have been discussed, particularly in American reports. ${ }^{12}{ }^{13} \mathrm{~A}$ consultative document has been issued by the Health and Safety Commission ${ }^{14}$ in Britain in which proposals are made that, "In order to safeguard the developing fetus from lead (1) pregnant women should be suspended from lead work and (2) a woman of child-bearing capacity should not be employed in lead work when her blood lead concentration exceeds $1.9 \mu \mathrm{mol} / \mathrm{l}$."
We thank the staff of the North Staffordshire Maternity Hospital for their help and co-operation and Dr D L Smith and Dr Barbara Ockenden for their advice and help.

\section{References}

1 Waldron HA, Stöfen D. Subclininal lead poisoning. London: Academic Press, 1974:124.

${ }^{2}$ Ferm VH, Carpenter CJ. Developmental malformations resulting from administration of lead salts. Journal of Experimental Molecular Pathology 1967;7:208-13.

${ }^{3}$ Stowe HD, Goyer RA. The reproductive ability and progeny of $F_{1}$ lead toxic rats. Fertil Steril $1971 ; 22: 755-60$.

4 EPA Health Implications of airborne lead. US Environmental Protection Agency 1973 November 28.

${ }^{5}$ Wilson AT. Effects of abnormal lead content of water supplies on maternity patients. Scott Med J 1966; 11:73-82.

6 Palmisano PA, Sneed RC, Cassady G. Untaxed whiskey and fetal lead exposure. J Pediatr 1969;75:869-72.

${ }^{7}$ Chisolm JJ, Backstrom J, Larsson KS. Pre-natal exposure and the effect on embryo and fetus. Workshop on the utility of an evaluated data bank in teratology and its use for a state-of-the-art report on adverse effects on lead on reproduction and development. Nynasharnn, Sweden: Swedish Council of Environmental Information, 1977 September 26-29:22-31.

${ }^{8}$ Wibberley DG, Khera AK, Edwards JH, Rushton DI. Lead levels in human placentae from normal and malformed births. J Med Gen 1977;14:339-45.

${ }^{9}$ Barlow PJ, Khera AK. Sample preparation using tissue solubilization by soluene-350 for lead determinations by graphite furnace atomic absorption spectrophotometry. Atomic Absorption Newsletter 1975;14:149-50.

${ }^{10}$ Khera AK, Wibberley DG. Some analytical problems concerning trace-metal analysis in human placentae. Proceedings of the Analytical Division of Chemical Society 1976;340-2.

${ }^{11}$ Schroeder HA, Tipton IH. The human body burden of lead. Arch Environ Health 1968;17:965-78.

12 Warshaw LT. Employee health sources for women workers. Prev Med 1978;7:385-93.

${ }^{13}$ Hricko A. Social policy considerations of occupational health standards - the example of lead and reproductive effects. Prev Med 1978;7:394-406.

${ }^{14}$ Health and Safety Commission Consultative document. Control of lead at work, draft regulations and draft approved code of practice. London: HMSO, 1978. 